\title{
Religion, human rights law and the rights of the child: complexities in applying the Sharia in modern state practices
}

\author{
JAVAID REHMAN ${ }^{*}$
}

Brunel University

\section{Introduction}

$\mathrm{T}$ The application of laws that are ostensibly divinely inspired remains a complex subject in today's world. ${ }^{1}$ The implementation of Islamic law, the Sharia, poses significant challenges to both constitutional practices and modern human rights law. ${ }^{2}$ The compatibility of the Sharia with modern human rights laws continues to provoke considerable heated yet inconclusive debate. ${ }^{3}$ The present article examines the rights of the child from the perspective of the Sharia with particular reference to its application in modern state practices. In highlighting the continued relevance of the Sharia principles in domestic laws, it engages with problematic yet contentious practices such as child marriages, the so-called "option of puberty", and the prohibition of adoption in classical

* Javaid Rehman is a professor of Islamic and international law and head of Brunel Law School, Brunel University. He is the rapporteur for the International Law Association's Committee on Islamic Law and International Law and is also a member of the association's Committee on International Family Law. This paper was delivered as a key-note presentation at an international conference entitled, "The Children's Convention at 21: The rights of the child come of age?" held at Ulster University in June 2010. The views contained in this paper are his own and do not represent those of any of the aforementioned committees. The author is thankful to his research assistant Stephanie Berry for useful research and assistance in the completion of this paper.

$1 \mathrm{~J}$ Rehman and S Breau (eds), Religion, Human Rights and International Law: A critical examination of Islamic law and practices (The Hague: Martinus Nijhoff 2007); J Rehman, "Conflicting values or misplaced interpretations? Examining the inevitability of a clash between 'religions' and 'human rights"' in N Ghanea (ed.), Does God Believe in Human Rights? (The Hague: Martinus Nijhoff 2006), pp. 65-88; A A An-Na'im, “The compatibility dialectic: mediating the legitimate co-existence of Islamic law and state law" (2010) 73 MLR 1.

2 See A A An-Na'im, Toward an Islamic Reformation: Civil liberties, buman rights and international law (Syracuse NY: Syracuse UP 1990); J Rehman, "Accommodating religious identities in an Islamic state: international law, freedom of religion and the rights of religious minorities" (2000) 7 International Journal on Minority and Group Rights 139; J Rehman, "Freedom of expression, apostasy and blasphemy within Islam: sharia, criminal justice systems, and modern Islamic state practices" (2010) 79 Criminal Justice Matters 4.

3 On children's rights within Muslim jurisdictions, see S S Ali, "A comparative perspective of the United Nations Convention on the Rights of the Child and the principles of Islamic law: law reform and children's rights in Muslim jurisdictions"' in S S Ali, S Goonesekere, E G Mendez, and R Rios-Kohn, Protecting the World's Children: Impact of the Convention on the Rights of the Child in diverse legal systems (Cambridge: CUP 2007), pp. 142-208; K Hashemi, "Religious legal traditions, Muslim states and the Convention on the Rights of the Child: an essay on the relevant documentation" (2007) 29 HRQ 194; S M Sait, "Islamic perspectives on the rights of the child" in D Fottrell (ed.), Revisiting Children's Rights (The Hague and London: Kluwer Law International 2000), pp. 31-50; S Langlaude, The Right of the Child to Religious Freedom in International Law (Leiden: Martinus Nijhoff 2007). 
interpretations of Islamic law. The paper argues that a narrow interpretation or application of the Sharia would violate child rights. However, the paper advances the argument that within the Sharia there is sufficient inbuilt latitude and flexibility to accommodate and ensure child rights as provided in the Convention on the Rights of the Child (CRC).

This article is divided into five sections. After the introductory section, section 2 highlights the relevance of Sharia for modern legal systems and in so doing assess its compatibility with human rights law. Section 3 examines the interaction of the Sharia with international provisions on the rights of the child as contained in the CRC (1989). Section 4 focuses on two particularly contentious aspects of children's rights within the Sharia - the legitimacy of child marriages and the prohibition of adoption. Section 5, the concluding section, offers a number of personal reflections on the subject.

\section{Relevance of the Sharia to modern social orders and the Sharia's compatibility with human rights law}

Amidst the wider analysis of the "war-on-terror" and the "clash of civilizations", Sharia's 4 compatibility with modern norms of human rights law forms a critical and charged debate. ${ }^{5}$ Muslims constitute approximately 20 per cent of the total world population. ${ }^{6}$ Projected estimates are that by the first quarter of the twenty-first century, Muslims are likely to reach 30 per cent of the global population. ${ }^{7}$ The continued relevance of Islam and Islamic law is highlighted by the consistent invocation of the Sharia principles within international, regional and national legal systems. ${ }^{8}$ Several states purport to place reliance on the principles of Sharia in implementing their domestic constitutional law and conducting their international relations. At present 15 constitutions name Islam as the official religion; five states have declared themselves to be Islamic republics. ${ }^{9}$ Sharia is not only relevant for those states which actively promote and claim to implement Islamic law within their domestic legal systems; Islamic legal principles have also been of increasing relevance in states such as the United Kingdom, France and the United States, which have significant Muslim minorities. ${ }^{10}$

In the European context, the requirements of the Sharia have been invoked in such contentious matters as the wearing of the veil, headscarves and jilbab at work and in

4 Islamic law is often referred to as the Sharia. The concept of the Sharia, however, is not confined to legal norms, but conveys a more holistic picture. See R Landau, Islam and the Arabs (London: George Allen Unwin 1958), p. 141.

5 See, generally, J Rehman, Islamic State Practices, International Law and the Threat from Terrorism: A critique of the "clash of civilizations" in the new world order (Oxford: Hart 2005).

6 W B Hallaq, An Introduction to Islamic Law (Cambridge: CUP 2009), p. 1.

7 S P Huntington, The Clash of Civilizations and the Remaking of World Order (New York: Simon \& Schuster 1996), p. 117; D McGoldrick, "Multiculturalism and its discontents" in N Ghanea and A Xanthaki (eds), Minorities, Peoples and Self-Determination (Leiden: Martinus Nijhoff 2005), pp. 211-35, p. 228.

8 LIAMCO Award 20 ILM (1981) 37, at 201; SCC Egypt Case No. 8 of Judicial Year 17 (18 May 2006) - for translation see N J Brown and C B Lonbardi, "The Supreme Constitutional Court of Egypt on Islamic law, veiling and civil rights: an annotated translation of Supreme Constitutional Court of Egypt Case No. 8 of Judicial Year 17 (May 18, 1996)" (2006) 21 American University International Law Review 437; Pakistan v Public at Large PLD 1986 SC 304; Iftikharuddin v Federal Government (1992) PLD FSC 188; Hazoor Bakhash v Federation of Pakistan (1980) PLD FSC 145.

9 M A Baderin, International Human Rights and Islamic Law (Oxford: OUP 2003), p. 8 (see text accompanying n. 33). According to an earlier study, there are 23 countries recognising Islam as the state religion. See IR al-Fariqi (ed.), Historical Atlas of the Religions of the World (1974), p. 279 cited in J L Payne, Why Nations Arm (Oxford: Blackwell 1989), pp. 122-3.

10 S Poulter, English Law and Ethnic Minorities (London: Butterworths 1986); S. Poulter, Ethnicity, Law and Human Rights: The English experience (Oxford: Clarendon 1998). 
educational institutions; ${ }^{11}$ formalities and the capacity to enter into a marriage; ${ }^{12}$ the validity of arranged or forced marriages; ${ }^{13}$ recognition of polygamous marriages $;^{14}$ the consequences of the talaq (unilateral divorce by the husband); ${ }^{15}$ and Muslim religious obligations during employment. ${ }^{16}$ The continued application of the Sharia in contemporary legal systems has inevitably led to question marks over its compatibility with modern human rights laws and constitutional practices at the domestic level. The subject is contentious and emotive and, not surprisingly, the opinions of international courts and jurists differ radically on this subject. In the Refah Partisi case, the European Court of Human Rights (ECtHR) held Sharia to be incompatible with human rights law. ${ }^{17}$ In accepting that the dissolution of the Refah Partisi (Turkish Welfare Party) - a party which had advocated the replacement of secularism with the Sharia - by the Turkish Constitutional Court was not a violation of freedom of expression or association as provided for in Articles 10 and 11 of the European Convention on Human Rights (ECHR), the court made the following observations:

like the Constitutional Court, the Court considers that sharia, which faithfully reflects the dogmas and divine rules laid down by religion, is stable and invariable. Principles such as pluralism in the political sphere or the constant evolution of public freedoms have no place in it. The Court notes that, when read together, the offending statements, which contain explicit references to the introduction of sharia, are difficult to reconcile with the fundamental principles of democracy, as conceived in the Convention taken as a whole. It is difficult to declare one's respect for democracy and human rights while at the same time supporting a regime based on sharia, which clearly diverges from Convention values, particularly with regard to its criminal law and criminal procedure, its rules on the legal status of women and the way it intervenes in all spheres of private and public life in accordance with religious precepts ... In the Court's views, a political party whose actions seem to be aimed at introducing the sharia in a State party to the Convention can hardly be regarded as an association complying with the democratic ideal that underlies the whole of the Convention. ${ }^{18}$

11 Jilbab is the plural for jilaabah, a term that refers to a long garment worn by Muslim women which normally covers the entire body except for the head, face and hands. See $\mathrm{R}$ (On the application of Begum (by her litigation friend, Rahman)) (Respondent) v Headteacher and Governors of Denbigh High School (Appellants) [2006] UKHL 15 (wearing of jilbab, a covering more extensive than hijab). On the veil, see Azmi virklees MBC, ET [2007] ELR 125, 6 October 2006, EAT [2007] ICR 1154, 30 March 2007. See also Bradford Corporation v Patel (1974) unreported (conviction of a Muslim father under the provisions of the 1944 Education Act for failing to send his daughter to a co-educational school on religious grounds).

12 On under-age marriages see Alhaji Mahammad v Knot [1969] 1 QB 1; [1986] WLR 1446, [1968] 2 All ER 563. See the Immigration Rules, paras 277 (Immigration and Nationality Directorate www.ind.homeoffice.gov.uk/ lawandpolicy/immigrationrules/part8. S Poulter, "The claim to a separate Islamic system of personal law for British Muslims" in S Mallat and J Connors (eds), Islamic Family Law (London: Graham and Trotman 1990), pp. 147-66.

13 See Hirani v Hirani (1983) 4 FLR 232; R v Immigration Appeal Tribunal, exp. Iqbal [1993] Imm AR 270.

14 See Quorasishi v Quorasishi [1983] FLR 706; Bibi v Chief Adjudication Officer (Gazette 94/27, 9 July, 22).

15 Quazi v Quazi [1980] AC 744; Chaudhary v Chaudhary [1985] FLR 476; Family Law Act 1986 (Part II); R v Secretary of State for Home Department ex p. Ghulam Fatima [1986] 2 WLR 693. See UK Visas Enquires www.ukvisas.gov.uk/servlet/Front?pagename $=$ OpenMarket $/$ Xcelerate $/$ ShowPage\&c $=$ Page\&cid $=103848915$ 6801.

16 See Ahmad v Inner London Education Authority [1978] QB 36, [1977] 3 WLR 396, [1978] 1 All ER 574 (Court of Appeal); Ahmad v UK (1982) 4 EHRR 126.

17 Case of Refah Partisi (the Welfare Party) and Others v Turkey, judgment of 13 February 2003 App. Nos 41340/98, 41342/98, 41343/98 and 41344/98, para. 123.

18 Case of Refah Partisi (the Welfare Party) and Others v Turkey, judgment of 31 July 2001, App. Nos 41340/98, 41342/98, 41343/98 and 41344/98, para. 72 (italics added). Cited in Case of Refah Partisi (the Welfare Party) and Others v Turkey, judgment of 13 February 2003 App. Nos 41340/98, 41342/98, 41343/98 and 41344/98, para. 123. 
In another case, Dablab v Switzerland, it was held that prohibiting a primary school teacher from wearing a headscarf was permitted in the circumstances, despite the fact that she had taught in the same school for three years without action being taken and without complaints being made. The ECtHR "[f]urther noted that the impugned measure had left the applicant with a difficult choice, but considered that State school teachers had to tolerate proportionate restrictions on their freedom of religion". ${ }^{19}$ More recently, the neutrality of the state education system was held to be a legitimate aim when restricting freedom of religion. This sentiment was echoed in Leyla Sabin v Turkey ${ }^{20}$ where the banning of headscarves by a university was held to be justified and proportionate to the aim. In Leyla Sabin, the applicant Ms Sahin complained that a rule established by Istanbul University prohibiting the wearing of the Islamic headscarf during classes and exams violated her Article 9 rights under the ECHR. ${ }^{21}$ Ms Sahin regarded wearing the headscarf as a religious obligation, and insisted that wearing the headscarf was a matter of personal choice and that such a personal decision was not incompatible with the principles of secularism as guaranteed by the Turkish constitution. ${ }^{22}$ The Turkish government contested the applicant's position and argued that the idea of secularism was vital to the Turkish state remaining a liberal democracy and that the headscarf represented an association with extreme "religious fundamentalist movements" presenting a threat to Turkey's value of secularism. ${ }^{23}$ The aforementioned cases indicate the ECtHR's view of the Sharia and its incompatibility and incongruity with evolving norms of modern human rights law in Europe.

At the other end of the spectrum, there is a significant amount of jurisprudence and legal literature, both within Europe and globally, to suggest compatibility between Sharia and human rights law and constitutional principles. ${ }^{24}$ Recent advocates of the acceptance of elements of Sharia within domestic law, and specifically the United Kingdom domestic law, have included the Archbishop of Canterbury, Dr Rowan Williams. ${ }^{25}$ A system of regulation of Muslim personal law has developed in the United Kingdom which, to a certain extent, achieves this aim. ${ }^{26}$ Sharia councils have existed in the United Kingdom since the 1970s, however, "voluntary compliance to Islamic laws in Britain can only pertain to matters concerning the family (marriage, divorce, maintenance, inheritance, etc.) and contractual relationships between two parties". ${ }^{27}$ Nevertheless, despite the controversy that surrounded

19 Dablab v Switzerland, judgment of 15 February 2001, App. No. 42393/98, 12.

20 Leyla Sabin v Turkey, judgment of 10 November 2005, App. No. 44774/98. See also Refah Partisi (the Welfare Party) and Others v Turkey, judgment of 13 February 2003, App. No. 41340/98, 41342/98, 41343/98, 41344/98.

21 Leyla Sabin v Turkey, judgment of 10 November 2005, App. No. 44774/98. paras 85-101.

22 Ibid. para. 85.

23 Ibid. paras 90-93.

24 See C G Weeramantry, Islamic Jurisprudence: An international perspective (Basingstoke: Palgrave Macmillan 1988); G Eaton, Islam and the Destiny of Man (Cambridge: Islamic Texts Society 1994); S S Ali, Gender and Human Rights in Islam and International Law: Equal before Allah, unequal before man? (The Hague: Kluwer Law International 2000); S Mahmassani, Arkan Huquq-al-Insan (Beirut: Dar-'ilmli'-Malayin 1979); S Mahmassani, “The principles of international law in the light of Islamic doctrine" (1966) 117(I) Recueil des Cours de l'Académie de Droit International 205; M A Baderin "Human rights and Islamic law: the myth of discord" (2005) 2 European Human Rights Law Review 165.

25 Archbishop of Canterbury, Dr R Williams, “Archbishop's Lecture - Civil and Religious Law in England: A religious perspective”, Royal Courts of Justice, 7 February 2008, www.archbishopofcanterbury.org/1575.

26 R C Akhtar, "British Muslims and the evolution of the practice of Islamic law with particular reference to dispute resolution" (2010) 6 Journal of Islamic State Practices in International Law 26; I Yilmaz, "Law as chameleon: the question of incorporation of Muslim personal law into the English law" (2001) 21 Journal of Muslim Minority Affairs 297.

27 Akhtar, "British Muslims”, n. 26 above, p. 28. 
the Archbishop of Canterbury's comments, ${ }^{28}$ some 85 informal Sharia councils are thought to operate in the United Kingdom. ${ }^{29}$ Further, the English courts have taken a positive attitude towards the Sharia in two recent cases: in Noah v Desrosiers t/ a Wedge an employment tribunal found indirect discrimination in a case where an applicant was not considered for a position at a hairdressing salon due to her wearing of the hijab; 30 and in Uddin v Choudhury and Others the court was willing to accept evidence of marriage under Sharia law. ${ }^{31}$

\section{International conventions and the interaction of the Sharia with child rights at the international and domestic levels}

The most pertinent international instruments related to children are the CRC ${ }^{32}$ and the Convention on the Elimination of Discrimination against Women. ${ }^{33}$ Both treaties, in raising concerns about the potential conflict with the Sharia, have been the subject of substantial reservations by Islamic states. Following the adoption of the CRC, a large number of Islamic states entered reservations or declarations either to the entire Convention or to specific provisions. ${ }^{34}$ Although several reservations have been based on constitutional and national laws, Ali makes the valid point that: "Muslim countries are unique in the fact that they have specifically identified the Islamic religion and Islamic law as justification for many of these reservations." 35 Further, these reservations have been a cause for concern, as the problem:

[i]s not so much with the number of reservations as it is with the nature and impact of the reservations that have been made. Many states, particularly, Islamic states, have made broad, general reservations that aim to modify or exclude the application of any provisions of the convention that are at variance with Islamic values and laws. ${ }^{36}$

While a number of Islamic states have made broad general reservations, described by Hashemi as "General Shariah based reservations", 37 a significant number of Islamic states have also made reservations to specific articles of the CRC. Article 14, on freedom of religion, and Article 21 in relation to adoption have, in particular, been subject to a significant number of reservations by Islamic states. Therefore:

28 See, for example, S Doughty and M Seamark, "Sharia law row: archbishop is in shock as he faces demands to quit and criticism from Lord Carey", Daily Mail, 9 February 2009, www.dailymail.co.uk/news/article512876/sharia-law-row-Archbishop-shock-faces-demands-quit-criticism-Lord-Carey.html; R Gledhill and P Webster, "Archbishop of Canterbury argues for Islamic law in Britain", The Times, 8 February 2008 www.timesonline.co.uk/tol/comment/faith/article3328024.ece; J Petre and A Porter, "Adopt Sharia law in Britain, says the Archbishop of Canterbury Dr Rowan Williams”, 8 February 2008, at www.telegraph.co.uk/ news/uknews/1578017/Adopt-sharia-law-in-Britain-says-the-Archbishop-of-Canterbury-Dr-RowanWilliams.html.

29 Akhtar, "British Muslims", n. 26 above, p. 29.

30 A bijab is a female head covering in the Islamic tradition, usually through a headscarf: Noah v Desrosiers $t / a$ Wedge [2008] Employment Tribunal Case No. 2201867/07 (29 May 2008).

31 Uddin v Choudhury and Others [2009] EWCA Civ 1205 (21 October 2009).

32 Adopted at New York, 20 November 1989. Entered into force 2 September 1990. UN GA Res. 44/25 Annex (XLIV), 44 UN GAOR Supp. (No. 49) 167, UN Doc. A/44/49 (1989) at 166; 1577 UNTS 3.28 ILM (1989) 1448.

33 International Convention on the Elimination of All Forms of Discrimination against Women, New York, 18 December 1979, UN, Treaty Series, vol. 1249, p. 13.

34 See W Schabas, "Reservation to the Convention on the Rights of the Child" (1996) 18 HRQ 472.

35 Ali, "A comparative perspective", n. 3 above, p. 142.

36 L J Leblanc, "Reservations to the Convention on the Rights of the Child: a macroscopic view of state practice” (1996) 4 International Journal of Children's Rights 357, p. 379.

37 Hashemi, "Religious legal traditions", n. 3 above, p. 198. 
[i]n the context of the Children's Convention, there are serious concerns that Islamic States parties will merely give formal recognition to some of the fundamental rights provisions laid down in the Convention without giving them substantive effect in domestic law. ${ }^{38}$ Additional impediments to the enforcement of the CRC, have been noted in relation to Islamic and Arab States, such as Jordan where "like many Arab countries, there are strong and deep-rooted tribal notions that the welfare of the collective supersedes that of the individual, and that children are the property of the collective family". 39

A particularly problematic subject has been that of the definition of the "child" within international law and within the Sharia. Article 1 of the CRC in providing a definition of the child, notes as follows:

For the purposes of the present Convention, a child means every human being below the age of eighteen years unless, under the law applicable to the child, majority is attained earlier.

This provision represents a compromise since states, especially those purporting to implement Sharia-based principles, differ in their views on the age of majority. At the same time the phrase "unless, under the law applicable to the child, majority is attained earlier" has seriously undermined any positive feature within this article. According to McGoldrick:

Article 1 clearly permits the national law of a State to provide that majority is attained at an age earlier than eighteen. Although that individual is then entitled to all the human rights of an adult, the special protection applicable to children no longer covers them. A minimum age limit for the declaration of majority by national laws should have been included. ${ }^{40}$

A lack of clarity - resulting from the position adopted by several Islamic states during the drafting stages of the convention - has led to unfortunate instances whereby domestic laws impose duties, obligations and criminal responsibility on children. The concepts of maturity and childhood are interrelated in Islamic legal traditions with the consequence that upon reaching maturity, the child:

is subject to all the rights, duties and responsibilities of an adult. These responsibilities and rights include criminal responsibility, the right to dispose of and possess his/her property as well as the right to make decisions regarding his/her marriage. ${ }^{41}$

While several Islamic states have accepted that 18 is the age of maturity, as contained in Article 1 of the CRC, huge inconsistencies still exist in relation to the permissible age of marriage and the age of criminal responsibility. Hashemi makes the point that at 15 , a child is legally regarded as having the age of maturity and the age of criminal responsibility in several states including Syria, Sudan, Pakistan and Iran. ${ }^{42}$ In relation to criminal responsibility in Nigeria, Ogunniran explains that while the Kaduna State Criminal Procedure Code forbids sentences of hudood or qisas under the age of taklif, this does not

38 S Syed, "The impact of Islamic law on the implementation of the Convention on the Rights of the Child: the plight of non-marital children under Shari'a" (1998) 6 International Journal of Children's Rights 359, p. 360.

39 L Hammad, "Rights in context: questioning universality in the implementation of children's rights using Jordan as a case study" in A Alen et al. (eds), The UN Children's Rights Convention: Theory meets practices (Antwerp: Intersentia 2007), pp. 3-21, p. 7.

40 D McGoldrick, "The United Nations Convention on the Rights of the Child" (1991) 5 International Journal of Law and Family 132, at p. 133.

41 Hashemi, "Religious legal traditions", n. 3 above, p. 198.

42 Ibid. p. 200. 
seem to have been implemented in practice. ${ }^{43}$ Further, the permissible age of marriage varies significantly in Islamic states, with Saudi Arabia not setting a permissible age and Iran setting the permissible age at 15 for boys and 13 for girls, raising additional questions of gender-based discrimination. ${ }^{44}$

An additional concept, which has been a cause of difficulty for several Islamic states, particularly in child custody cases, is that of "the best interests of the child". Article 3(1) of the CRC provides:

In all actions concerning children, whether undertaken by public or private social welfare institutions, courts of law, administrative authorities or legislative bodies, the best interests of the child shall be a primary consideration.

In this respect, Egypt has argued "that the best interests of a child: "would inevitably have to take into account the environment, conditions and customs in a given society; the best interests of the child could not refer to a uniform standard throughout the world"'. ${ }^{4}$ The application of this principle raises particular issues in marital disputes involving custody and guardianship of children. Islamic law specifies a difference between hiznat (custody) and guardianship. Hashemi notes:

[a]nother distinction is that [Islamic law] recognizes specific rules in regard to the custodial rights of either the father or the mother. In the case of divorce, deciding custody issues in [Islamic law] was primarily based on the child's age, rather than "the child's best interests". 46

Ali in this respect argues:

One does not come across any verse of the Quran establishing the father as the sole legal guardian. However, there is a saying of the Prophet Mohammed (PBUH), which is an extract of his sermon on the occasion of the Last Pilgrimage (Hijjat-ul-Widah) to the effect that "[T] he child belongs to him/her on whose bed it is born." Within the patriarchal set up of society, the man (in this case the husband) has to provide the household effects including the bed on which the child is born. It is therefore inferred that the child belongs to the father. This is in line with the earlier mentioned Islamic law argument of the father being made to pay for feeding and rearing his child even if it be by the child's own mother. But it may be argued here that these injunctions/recommendations are always prefaced by the economic superiority of the man. The question that we would like to pose here is: What would be the position if one was to reverse situations and the woman/mother was the breadwinner/provider of the family? Another thought that surfaces here is that in the Quranic verses on joint parental obligations regarding child rearing, the emphasis is on consensus. If the father was the sole "owner" of the child, it would enable him to exercise arbitrary powers within these relationships and

43 Hudood is the plural of had, which refers to a crime against the law of God. Seven crimes are specified within the Muslim holy book, the Quran, and for which prosecution and punishment in case of guilt is deemed mandatory. Qisas (or quesas) are crimes against the person, such as murder, homicide, maiming, serious bodily harm. The Sharia provides for retaliation or compensation (diyya) once guilt is established. Taklif is legal responsibility. I Ogunniran, "The Child Rights Act versus Sharia law in Nigeria: issues, challenges and a way forward” (2010) 30 Children's Legal Rights Journal 62, p. 69.

44 See, generally, L Askari, "The Convention on the Rights of the Child: the necessity of adding a provision to ban child marriages" (1998) 5 ILSA J Intl and Comp L 123, p. 124.

45 S Harris-Short, "International human rights law: imperialist, inept and ineffective? Cultural relativism and the UN Convention on the Rights of the Child" (2003) 25 HRQ 130, pp. 152-3 quoting Egypt, Summary Record of the 680th Meeting: Egypt, UN Committee on the Rights of the Child, UN Doc. CRC/C/SR.680, 51.

46 Hashemi, "Religious legal traditions", n. 3 above, p. 213. 
the best interests of the child would not be of primary consideration as it presently is. 47

The award of automatic legal guardianship (or wali) to the father and the decision to grant custody based on age rather than upon the principle of the best interests of the child departs radically from the spirit and provisions of the CRC. As the second periodic report from Pakistan noted:

$[\mathrm{u}]$ nder the provisions of Islamic law, as applied in Pakistan, the general rule is that custody of a boy who has not attained the age of 7 and that of a girl who has not attained puberty is to remain with the mother. The male child up to this age, and the female child during most of her young age, is considered to be better off in the custody of the mother. ${ }^{48}$

Notwithstanding the overwhelming ratification of the CRC, domestic courts within Islamic states regularly interpret the Sharia to the detriment of the mother and girl child. ${ }^{49}$

\section{Child rights and the issues facing the Islamic world - the application of kafalah, child marriages and the "option of puberty"}

The central argument which this paper advances is that a rigid application of the Sharia principles not only negates the provisions of the CRC, but would also be hugely detrimental to constitutional principles designed to ensure the welfare of the child within domestic legal frameworks. In order to illustrate this point, two examples are presented. These relate, firstly, to issues arising from the Islamic systems of child marriage and the so-called "option of puberty" and, secondly, to kafalah. ${ }^{50}$ In each instance, although complication arises through the application of the Sharia within Islamic states, there are transnational legal consequences. The first controversial example, as noted above, relates to the age of marriage and the so-called "option of puberty" existing and being valid within modern Islamic states. As already observed, within Islamic states the permissible age of marriage varies

47 Ali, "A comparative perspective", n. 3 above, p. 158.

48 A A A Fyzee, Outlines of Muhammadan Law (Delhi: OUP 1974), pp. 208-9. Committee on the Rights of the Child: Consideration of Reports Submitted by States Parties Under Article 44 of the Convention, Second Periodic Reports of States Parties due in 1997 (CRC/C/65/Add. 21) (11 April 2003) para. 89. This position was confirmed by the High Court of Justice in Mst Farab Iqbal (Petitoner) v Mubammad Anwar and Two Others (Respondent) where the court made the following observations: "Decisions relating to [the] custody of minors are regulated under Islamic Personal Law and there is [a] consensus amongst the Muslim jurists that, for her right of custody (hizanat) the mother is entitled to keep . . . custody of [a] male child up to the age of 7 years, when he becomes independent, himself capable of [taking care of himself], drinking, eating and performing other natural functions without assistance and thereafter the custody devolves upon the father or next parental relation. Thus the right of the mother to custody in respect of [a] male child ceases at the age of 7 years. The right of 'Hizanat' qua a female child pertains to [the] mother till the appearance of menstrual discharge i.e. [the] age of puberty. Thereafter, [the] father becomes entitled to the custody of [a] female child. [Moreover], the mother['s] . . custody of [the] child becomes disentitled or [she] loses the right of custody of a minor on the following grounds: (1) If she marries a person not related to the female child within the prohibited degree; or (2) If she goes to reside during the subsistence of the marriage, at a distance from the minor's father's place of residence; (3) If she is leading an immoral life, as . . . a prostitute; or (4) If she neglects to take care of the child." See Mst Farah Iqbal (Petitioner) v Muhammad Anwar and Two Others (Respondents) Constitutional Petition N370 of 2002, decided on 7 April 2003; PLD 2003 Quetta 131, at 134.

49 For the case of Iran, see Z Mir-Hosseini, Marriage on Trial: A study of Islamic family law in Iran and Morocco; Islam and gender (London: IB Tauris 2000).

50 Kafalab is a voluntary undertaking to take care of a minor, including maintenance and protection of the minor in a manner similar to the natural parents towards their child. Kafalab has some similarities with but, in the light of major differences, is not regarded as equivalent to adoption. Kafeel describes a person who undertakes kafalah. See F Pereira, The Fractured Scales: The search for a uniform personal code (Calcutta: Stree 2002); T Monsoor, Judiciary and Gender on Trial: Reported and unreported decisions of family courts (Dhaka: British Council 2004). 
significantly. Saudi Arabia has not set a permissible age, Iran permits lawful marriages for boys at 15 and 13 for girls, Muslim child marriages (sanctioning the marriage of girls as young as nine) continue to be deemed lawful within the South Asian traditions of Pakistan and Bangladesh. ${ }^{51}$ It is also the case that certain Islamic schools including the predominant Islamic school, the Hanafi school, grant authority to the parent or the guardian (wali) to enforce child marriages, with the so-called "option of puberty". Thus, as one scholar has put it "under the Muhammadan law of all schools, the father has the power to give his children of both sexes in marriage without their consent, until they reach the age of puberty". 52 Under this interpretation of Muslim family laws, the guardian's power to agree to the child marriage comes to an end once the child has attained the age of puberty. Once the child has reached the age of puberty, he or she could invoke the "option of puberty" in order to rescind the marriage provided that the consummation of marriage has not taken place. ${ }^{53}$

The "option of puberty" is legitimised and legislatively enshrined within the constitutional frameworks of several modern Islamic states. In Pakistan and Bangladesh, in legitimising the "option of puberty" the Dissolution of Muslim Marriage Act (1939) (as amended by the Muslim Family Law Ordinance 1961) provides:

\section{Grounds for decree for dissolution of marriage.}

A woman married under Muslim law shall be entitled to obtain a decree for the dissolution of her marriage on any one or more of the following grounds, namely:

... that she, having been given in marriage by her father or other guardian before she attained the age of [eighteen ${ }^{54}$ years, repudiated the marriage before attaining the age of [nineteen ${ }^{55}$ years: Provided that the marriage has not been consummated

Contrast this legislative authority and considerable rampant practices of child marriages to the vocal criticism and condemnation, emanating from and including the Islamic world. Thus, the Rabat Declaration on Child Issues calls "upon all Member States to take the necessary measures to eliminate all forms of discrimination against girls and all harmful traditional or customary practices, such as child marriage and female genital mutilation". 56 While no provision in the CRC explicitly refers to child marriage, it is patently obvious that child marriages would violate fundamental principles, such as the right to life (Article 6), the right to health (Article 24), the right to be protected from harmful practices (Article 24), the right to freedom from abuse and exploitation (Articles 19, 34, 39), contained within the CRC. ${ }^{57}$ Having regard to these concerns, the Committee on the Rights of the Child considered the minimum age for marriage during its general discussion day on the girl child:

The Committee had also identified certain areas where law reform should be undertaken, in both the civil and penal spheres, such as the minimum age for marriage and the linking of the age of criminal responsibility to the attainment

51 For a survey of the relevant legal position, see www.law.emory.edu/ifl/. A A An-Na'im, Islamic Family Law in a Changing World: A global resource book (London: Zed Books 2002).

52 Fyzee, Outlines of Mubammadan Law, n. 48 above, pp. 208-9.

53 D Pearl and W Menski, Muslim Family Law (London: Sweet \& Maxwell 1998), p. 157, also see Said Mohammod $\mathrm{v}$ The State, PLD 1995 FSC 1.

54 Substituted by s. 2 of the Muslim Family Laws Ordinance (VIII of 1961).

55 Ibid.

56 Rabat Declaration on Child's Issues in the Member States of the Organization of the Islamic Conference www.isesco.org.ma/english/.../Final\%20Agreed\%20Declaration.pdf.

57 See International Planned Parenthood Federation and the Forum on Marriage and the Rights of Women and Girls, Ending Child Marriage: A guide for global policy action (London: IPPF 2006), p. 25. 
of puberty. In several States the minimum age for marriage was different for girls and boys. To explain this, States had often argued that girls attain physical maturity earlier. However, maturity cannot be identified simply as physical development; social and mental development also had to be taken into account. Moreover, on the basis of such criteria, girls are considered as adults before the law upon marriage, thereby being deprived of the comprehensive protection of the Convention. 58

Furthermore, Article 16(2) of the Convention on the Elimination of Discrimination against Women states " $[\mathrm{t}]$ he betrothal and the marriage of a child shall have no legal effect, and all necessary action, including legislation, shall be taken to specify a minimum age for marriage and to make the registration of marriages in an official registry compulsory". 59 Notwithstanding the denunciation of child marriages, this practice persists alongside the application of the so-called "option of puberty". The combined effect of child marriage and the application of the "option of puberty" result in a valid marriage for minors, provided the guardian was an adult with a sane mind and able to provide an effective consent. Recent years have witnessed the extension of the application of the "option of puberty" not only to minors, but also to adults without the capacity to provide a valid consent, such as those with mental disabilities. This point was substantiated in the case of City of Westminster $\mathrm{v} I C$ and $K C$ and NNC. ${ }^{60}$ In this case, the issue before the English courts was whether consent given to marriage by the father of a 26-year-old man (who was himself suffering from autism) was valid consent for the purposes of telephonic marriage conducted with an adult and sane woman in Bangladesh.

In his judgment of December 2007, Mr Justice Roderic Wood (dated 21 December 2007) made the following observations:

\section{Is IC's "Marriage" Lawful in Sharia Law and Bangladesh Civil Law?}

I have recorded above the unanimity of view that IC's marriage is lawful both in Sharia and in Bangladeshi civil law ...

Despite IC's incapacity to consent, a mentally incapable adult can contract a legally valid marriage under Islamic law. I need not set out the bulk of the conditions, but what is essential is that for these purposes IC has a guardian (a marriage guardian) who has full mental capacity, and who has the right to give his consent for his son's marriage, notwithstanding the incapacity of IC.

A further requirement is that the bride, in this case NK, was herself without disability, and consented freely. She is and she did.

Irrespective of IC's ability or inability to consent, the father of IC (his marriage guardian) "may legitimately act in the best interests of his Ward to arrange, solemnise and contract a marriage for that individual which binds that individual and the spouse in all respects". (paras 53-9)

This point remained valid and was accepted by the Court of Appeal on appeal in the decision of Roderic Wood J. ${ }^{61}$

58 CRC, General Discussion on the Girl Child, UN Doc. CRC/C/38 [294] www2.ohchr.org/english/ bodies/crc/discussion2008.htm.

59 See J Rehman, International Human Rights Law (London and New York: Longman 2010), pp. 520-54.

60 City of Westminster v IC, KC and NNC [2007] EWHC 3096.

61 See KC and Another v City of Westminster Social and Community Services Department and Another [2008] EWCA Civ 198, paras 32 and 49. 
While they have undertaken the international obligations (as contained in the CRC and the Convention on the Rights of Persons with Disabilities 2007), ${ }^{62}$ a number of Islamic states continue to legitimise sexual abuse of disabled persons under the guise of the Sharia. In order to ensure respect for the dignity and physical health of disabled persons, such exploitative practices must come to an end.

The second, controversial, example relates to the application of the Sharia laws on kafalah. ${ }^{63}$ Sharia, as is well known, does not recognise a Western-style concept of the adoption of minors. In prohibiting adoption, the Sharia offers the alternative scheme of kafalah. Ali has elaborated upon the purposes of prohibition on adoption in Islamic law which:

were to contain and, in certain cases, to root out social evils. For example, the tribal Arab psyche of "accumulation" if one may use the term, of male children provided extra hands during tribal warfare, and so on ... Second, the issue of adopted children coming within prohibited degrees of relationship had to be considered ... Third, the right of a child to be informed of and give the right to use his parents' identity was sought to be established. ${ }^{64}$

Further, the Organization of the Islamic Conference Declaration on the Rights and the Care of the Child in Islam proclaims:

Islam has given every child the inalienable right to a relationship of lineage to his or her "father". Therefore, Islam prohibits adoption because it deprives the child of this right. At the same time, Islam does not prevent any family from providing Kafalah to and caring for a child alien to the family. Indeed, Islam strongly urges such deeds. ${ }^{65}$

The kafalah system differs radically from the English law on adoption including the following obvious distinctions. Firstly, the adopted child retains the surname of his or her biological parent and does not take the name or identity of the adoptive parent. Secondly, the adopted child does not have any automatic entitlement to inheritance from the adoptive parents and inherits from the biological parents. Thirdly, and most crucially, the adopted child is not regarded as a blood relative and, therefore, cannot be regarded as mahram to members of the adopting family. Hence, once the child grows, he or she is not within a category which prevents marital relations amongst members of the adopting family. ${ }^{66}$ This later aspect was characterised in the personal experience of the Prophet Mohammad (PBUH), the Prophet of Islam, whereby he was able to marry his adopted son's divorced wife: the abolition of the practice of adoption, allowed the Prophet to renounce the hitherto relationship between himself and his adopted son, Zaid, and his divorced wife Zinayab. The varying schools of Sharia reflect considerable flexibility in the operation of kafalah, and there is clearly no doubt again from the examples of the Prophet's own tradition (the Prophet himself being an orphan) of the paramount nature of love and care

62 Adopted by the UN General Assembly during its 61st Session: see GA Res. 61/611 (13 December 2006) A/61/611; 15 IHRR 255.

63 See S Ishaque, "Islamic principles on adoption: examining the impact of illegitimacy and inheritance related concerns in context of a child's right to an identity" (2008) 22 International Journal of Law, Policy and the Family 393; J H Chamberlayne, "The family in Islam" (1968) 15(2) International Review for the History of Religions 119-41; $\mathrm{J}$ Bargach, Orphans of Islam: Family, abandonment, and secret adoption in Morocco (Lanham MD: Rowman \& Littlefield 2002).

64 Ali, "A comparative perspective", n. 3 above, p. 154

65 Declaration on the Rights and Care of the Child in Islam, www.oic-oci.org/english/conf/fm/22/ resolution22-c.htm\#16.

66 Mahram is a kin with whom marriage or a sexual relationship is prohibited. See J Bargach, "A study on abandonment and the practice of Kafala in Morocco for Amici Dei Bambini", www.childout.org/ data/doc/doc_e7f9dc3540c6be0a3b79ac8d90e02b07.pdf. 
for orphans and needy children. ${ }^{67}$ Under the kafalah, adopted children may be given gifts and bequests made in their favour. Similarly, Sharia principles establish that, in instances where the adopted child is raised by the kafeel mother through breastfeeding, it establishes the bond of being a mabram thereby preventing the possibility of any subsequent marital relationship either with the mother or with the siblings in the family.

The concept of kafalab is recognised by the CRC in Article 20 which states:

1. A child temporarily or permanently deprived of his or her family environment, or in whose own best interests cannot be allowed to remain in that environment, shall be entitled to special protection and assistance provided by the State.

2. States Parties shall in accordance with their national laws ensure alternative care for such a child.

3. Such care could include, inter alia, foster placement, kafalah of Islamic law, adoption or if necessary placement in suitable institutions for the care of children. When considering solutions, due regard shall be paid to the desirability of continuity in a child's upbringing and to the child's ethnic, religious, cultural and linguistic background.

Article 21 continues: "States Parties that recognize and/or permit the system of adoption shall ensure . ..": consequently, State Parties that do not recognise adoption are not obliged to abide by this provision. While the CRC, clearly does not try to enforce adoption in states where it is not permitted, a number of Islamic states have nevertheless lodged reservations in this respect. Syria explains that:

The laws in effect in the Syrian Arab Republic do not recognize the system of adoption, although they do require that protection and assistance should be provided to those for whatever reason permanently or temporarily deprived of their family environment and that alternative care should be assured them through foster placement and kafalah, in care centres and special institutions and, without assimilation to their blood lineage (nasab), by foster families, in accordance with the legislation in force based on the principles of the Islamic Shariah. ${ }^{68}$

Notwithstanding this broader interpretation, Islamic kafalah continues to pose problems. In the Islamic world, a significant majority of the children placed in kafalah are abandoned children or are orphans. An inability to adopt the identity and to inherit from the adopting parents is particularly unfortunate for those who have been condemned by the state as well as the society. A further highly tragic consequence in the existing manipulative societies is the probable risk of sexual or physical abuse of young vulnerable children, especially if these minors are not to be regarded as mahram. The implementation of kafalah across national jurisdictions is equally problematic. Thus, if a family from the UK intends to undertake an adoption in a country such as Morocco which allows international adoptions, there remain serious impediments. Firstly, the kafeel parents have to be Muslims. ${ }^{69}$ Once they are able to satisfy the local judge of their ability to act as kafeel parents, an order can be made in their favour. However, they are never in real terms recognised as the equivalent of adoptive parents. The child's guardianship remains in the

67 Ali, "A comparative perspective", n. 3 above, p. 153

68 http://treaties.un.org/Pages/ViewDetails.aspx?src=TREATY\&mtdsg_no=IV-11\&chapter=4\&lang=en.

69 See Bargach, "A study on abandonment", n. 66 above. 
control of a local judge, the Judge of Minors' Affairs. ${ }^{70}$ The judge oversees that the conditions of adoption are complied with, including education and upbringing. A failure to comply with these conditions will allow the judge to terminate the kafalah. ${ }^{71}$ In order to provide for any inheritance, the kafeel parents need to approach the Judge of Minors' Affairs who prepares the relevant documents. In order to take the child abroad, specific permission is needed from the Judge of Minors' Affairs. If the child is to reside abroad, the consulate of the country is required to consistently provide the Judge of Minor's Affairs with a follow-up report on the conditions of the adopted child. These requirements of kafalah, as in the case of Morocco, have raised considerable difficulties, in particular for couples wishing to undertake international adoptions. In the face of such stringent requirements, courts are often challenged as how best to deal with the kafalab orders delivered under Islamic jurisdictions. ${ }^{72}$

\section{Comprehending the Sharia - flexibility and reform process within Islamic state practices: concluding reflections}

Analysed through the spectrum of such abominable practices as child marriages or enforced marriages for persons with disabilities, the legitimacy of the Sharia is substantially undermined. The critics of the Sharia would therefore endorse the scepticism expressed by the ECtHR over Islamic law's ability to offer compatibility with the changing human rights values. Similarly, states following the Sharia could never legitimately claim to protect child rights within modern societies. Fortunately, the picture is not as bleak as the critics of the Sharia might portray. The difficulty is not so much with the application of the Sharia within modern domestic frameworks as it is with the interpretation and continual reform within Islamic legal traditions. Laws sanctioning child marriages (or authorising the father or guardian to have the right to marry children or wards) performed under the "option of puberty" represent archaic segments of indigenous tribal traditions - these traditions persist, preventing reform movements projected by the Sharia or by modern human rights laws. Child marriages, enforced marriages or discrimination against the girl child have not only been issues within Muslim societies, but are phenomena with historic roots in South Asia, the Americas, Africa and Europe. The Sharia, with a literal meaning of "path to the running water", has a reform mechanism built into it, with substantial possibilities of evolution within Islamic legal traditions. The true essence of the Sharia is brought out by Parwaz who notes that: " $[\mathrm{t}]$ he sharia refers to a straight and clear path and also to a watering place where both humans and animals come to drink water, provided the source of water is a flowing stream or spring". ${ }^{73}$ It is, therefore, as another scholar argues "no slight irony

70 According to Article 7 of the "Adoption of Neglected Children (Kafala)" 01-15, issued by Dahir number 1.02.172 (2002) of Morocco "the judge . . responsible [for] . . minors['] affairs has the right of custody or guardianship ... [of] neglected children for the prosecution of legitimate and legal prosecution[s] provided in the Personal Status Code and the Code of Civil Procedure", www.sgg.gov.ma/BO/bulletin/Ar/2002/ BO_5031_ar.pdf.

71 Ibid. Article 24.

72 Re J (Adoption: Consent of Foreign Public Authority) [2002] EWHC 766 (Fam); [2002] 2 FLR 618; [2002] 3 FCR 635; [2002] Fam Law 651; Newcastle City Councilv Z (S (A Child), Re) [2005] EWHC 1490 (Fam); [2007] 1 FLR 861; [2007] Fam Law 10; Re Dra (Unreported, 24 March 2004) (CE (F)) (commentary available (2005) (Autumn) PL 658-60).

73 GA Parwez, Lughat-ul-Quran: Lexicon of the Quran 4 vols (Tulueislam 1960), p. 941. 
and tragedy that the sharia, which has the idea of mobility built into its very meaning, should have become a symbol of rigidity for so many in the Muslim world". ${ }^{74}$

The Sharia has made numerous positive contributions, such as the prohibition of infanticide, the enhancement of the rights of the girl child and restraining polygamous marriages. ${ }^{75}$ In a similar vein, as has been considered earlier, the kafalah system in itself is not antithetical to promoting and protecting the best interests of the child. There are considerable examples within Islamic traditions to reflect both the positive features as well as flexibility in the kafalah system - there is no doubt from the examples of the Prophet's own tradition of the paramount nature of love and care for orphans and needy children. Under the kafalab system, adopted children can be given gifts or bequests. Similarly, the Sharia principles establish that in instances where the adopted child is raised by the kafeel mother through breastfeeding, it establishes a bond of being a mahram thereby preventing the possibility of any subsequent marital relationship either with the mother or with the siblings in the family. If allowed to prosper and develop, over a period of time, the Sharia principles would undoubtedly shed all discriminatory actions and amalgamate wholeheartedly the evolving norm of child rights and gender-based equality.

74 R Hassain, "The role and responsibilities of women in the legal and religious tradition of Islam", paper presented at a biannual meeting of a Trialogue of Jewish-Christian-Muslim scholars on 14 October 1980 at the Joseph and Rose Kennedy Institute of Ethics, Washington, DC, USA, p. 4.

75 See J Rehman, "The sharia, Islamic family laws and international human rights law: examining the theory and practice of polygamy and talaq" (2007) 21 International Journal of Law, Family and Policy 108. 